\title{
The Subjectivity of Forced-migrant in Poems of and by Refugees
}

\author{
Nurhadianty Rahayu \\ nurhadianty.rahayu@gmail.com \\ English Department, STKIP La Tansa Mashiro, Banten, INDONESIA
}

\begin{abstract}
Refugees' perilous experiences force them to flee home for safety. Their arrival from home country to the host country is not only often reduced to be a statistical number in factual reports but also seen as threats to national well-being. The study aims to provide the argument that poems provide a symbol of resistance towards refugees' given fate, and offer a platform for them to create their authentic version of knowledge. Poems are chosen to be analyzed in this study as they can mediate the refugees' unique experiences and their struggle to cope with the changing condition. The study argues that poems of and by refugees can serve as strategic means of preserving memories that connect them with their past, which shape their present and construct an alternative subjectivity against objectification and stereotypes pinned to them. Poems analyzed in this research are 'Home' by Warsan Shire, 'The Icebreaker' by Yovanka Paquete Perdigao, and 'Empathy' by A.E. Stallings. Those excerpts are interpreted through Feminist Refugee Epistemology (FRE), which according to Espiritu (2018), "reveals the hidden political forces within the site of intimate domestic interaction in each refugee's unique experiences and queer sociality." The study concluded that poems of and by refugees could facilitate the forced-migrants' aspiration and create alternative knowledge as opposed to their common objectification in mass-media reports.
\end{abstract}

Keywords: feminist refugee epistemology, refugee, subjectivity

\section{Introduction}

Refugees' experiences, who flee home because of state violence, civil war, or colonization, are often mentioned in the brief news reports as a percentage only, if not as a threat to national wellbeing. Moore et al. in Chouliaraki \& Zaborowski (2017) stated that the refugee was a victim of war and conflict in need of protection but also a threat to 'our' community of belonging. The brief description of their perilous journey to safer countries is not portrayed thoroughly as their stories are covered if accidents occur or if they are taken as captives by the local authority in a detention center, as exemplified by the letter from Manus Island detention center written by Boochani (2018). Unlike news coverage of the refugees that depicts them as both passivized and collectivized beings (Chouliaraki \&
Zaborowski, 2017), poems are seen as the artistic means that allow them to articulate their narratives in the form of poetic expression. Through this media, refugees can revive their existence and subjectivity within their hard circumstances against the portrayal as victims to be pitied (Anna-Leena Toivanen, 2017). Poetic forms as an expression of indepth familiarity of bitter experiences which reveal despair and agony of being rejected while seeking for the safer condition can act as both psychical remedy and political voice in a state where the power holders fail to create an inclusive environment in the host country.

The refugees' state of homelessness because of civil war, state terrors, and violence help create the sense of 'un-belonging' that in some societies include the lack of basic material needs such as food and shelter, and in 
others, displacement is emotional and intellectual (Shields, 2018). Home is, thus, paramount to articulate the condition of the refugees, which shapes their shifting geopolitical identity. However, this notion of home is ambivalent because it tends to be closed tight with the idea of 'returning.' For refugees, "Return is filled with genuine terror: threats of persecution, imprisonment, or unspeakable violence" (Castellani, 2019). Immigrant literature, Castellani (2019) stated, "mostly falls into one of two archetypes: a character leaves behind a place to embark on a personal quest; or a character enters an unfamiliar country, where they are a stranger to most, and finds they must navigate its codes and culture to survive." The refugees as forcedmigrants also experience similar journeys; only it is more predicated and tragic, whose end is uncertain.

Perspectives about the journey, home, and troubled return help to drive the conducting of this study. The focus of the investigation is on how personhood and subjectivity are reflected in the poems of and by refugees. The poems scrutinized are "Home" (Warsan Shire, n.d.), "The Icebreaker" (Yovanka Paquete Perdigao, 2015), and "Empathy" (Stallings, 2018). The lens through which the interpretation of the investigation takes shape is Feminist Refugee Epistemology (FRE) within the context of refugees' experiences in their poems highlighting the forced-migration crisis.

Refugee crisis analyzed through literary writings have been done to portray refugees, and their relation with border policy, warfare, conflicts, global inequalities and liminal spaces (Boochani, 2018; Gallien, 2018a; Sakr, 2018; Sellman, 2018; Surma, 2018); other studies observe literary writings highlighted refugees' journey on the sea (Anna-Leena Toivanen, 2017; Stan, 2018) and most of them are scrutinized through the lens of postcolonial theory.

The three poems are scrutinized and interpreted by the help of Feminist Refugee Epistemology (henceforth FRE) that is introduced by Espiritu \& Duong. To resist the portrayal of refugees as the utmost sufferers and naturalized victims of military brutality,
Le Espiritu \& Duong (2018) propose FRE to reconceptualize war-based displacement as social reproduction and innovation. Borrowing the viewpoint of feminist epistemology, FRE places the refugees' position as the marginal, the oppressed, and the excluded whose personal experiences are the site of power contestation and reproduction (Shalhoub-Kevorkian in Le Espiritu \& Duong, 2018).

The urge to investigate poems of and by refugees emerge due to most research articles analyzed fiction, personal narratives, passbook, and letters (Boochani, 2018; Hopkins, 2009; Lewis, Rodgers, \& Woolcock, 2008; Saint, 2012; Sakr, 2018; Surma, 2018), while the comprehending of this phenomena through poems is still minimal. In addition to the postcolonial theory used to observe the refugee literary works (Anna-Leena Toivanen, 2017; Cahill-Booth, 2013; Gallien, 2018b, 2018c; Stan, 2018), FRE enriches refugees' poems elucidation, particularly regarding its role to provide valid subjectivity enacted by the poet-refugee and activist-poet.

\section{Methodology}

The three poems under scrutiny in this study are about refugees' experience by exrefugees, i.e., Warsan Shire and Yovanka Paquete Pedrigao, and the involvement of nonrefugee who is also a poet/refugee activist A. E. Stallings. All of them are women, which help the study to interpret refugee's experiences in their viewpoints whose political forces operate within the site of intimate domestic interaction and queer sociality (Le Espiritu \& Duong, 2018). The selection of the poems is to highlight the personal history and recollection of memory as a reconstructed knowledge. The poetic expression of Shire, Pedrigao, and Stallings is a hopeful battleground that deconstructs the gap of global injustice in the context of the refugee crisis from which the poets form a new meaning-making.

The study decides to analyze the three poems by women because of the particularity of women's experience that has a strong correlation with their biological and social roles as women and mothers. The poems display the collision of the individual plight 
and how the voice in articulated activates new meaning-making.

\section{Feminist Refugee Epistemology in Scrutiny of "The Icebreaker", "Home", and "Empathy"}

Le Espiritu \& Duong (2018) criticize public hyperfocus on refugees' suffering instead of doing a more in-depth analysis of the geopolitical cause of their displacement. This becomes the point of departure to see the out-of-sight struggles the refugees took to overcome the effect of war Hyndman (2010) and Lubkemann (2008) in Le Espiritu \& Duong (2018). In line with the reconceptualization of war-based displacement, the FRE-shaped interpretation on the three poems: "The Icebreaker"; "Home"; and "Empathy", tries to investigate the portrayal of refugees as a subject who can construct their meaningmaking and tell their authentic experience as an act of struggle as well as survival decisionmaking.

"The Icebreaker" is a perfect specimen that reflects poetical voice as an active subject who fosters uneasiness as the trigger of conversation in public socialization. "Home" represents the shared experience of refugees making a quick, dangerous decision to flee home because home is no longer a place to return to. This poem helps readers to fathom the unattainable horror of refugees' forced migrant phenomena. "Empathy" lets the readers question their position as the privileged that should not take their ordinary life for granted in the face of the refugee's crisis.

The three poems contribute to FRE in terms of their trigger to form a new meaningmaking of peace, home, and social encounters after experiencing the tragic migratory journey as known facts and personal suffering that intersect within the context of poetic expression. The mirror of social interaction that involves refugee's experience as the topic of public small talk in "The Icebreaker" reflects the realm of "feelings and emotion, in order to search for the quiet ways to subjugated refugees stories to get (re)told" (Le Espiritu \& Duong, 2018).
The voice in Shire's "Home" speaks for the shared experience of refugees, because displaced people know, remember, and transmit the feeling and emotion they feel when making their refuge voyage to the unknown. The private grief in the past is no longer a historical artefact, but "constitutes a feminist refugee practice of 'critical juxtaposing'- the deliberate bringing together of seemingly different memories to make visible the subversion" (Le Espiritu in Le Espiritu \& Duong, 2018). The different memories circulated are those that relates to the effect of migratory journey, such as the act of walking through the desert and crossing the oceans, tearing one's passport to be able to leave 'home' behind forever, the experiences of being beaten by the border guards, the imprisonment, and the refusal by the local people upon their arrival. Those experiences are several representations of refugee's shared memories as well as personal loss and despair that intertwine with the public acceptance of what they had gone through the poem. In this light, FRE sees the intersection of refugee's personal and emotional circumstances with public experiences as not only historical artifact but an authorized meaning, if not, knowledge-making. They own their shared personal trauma, and they hold the right to authorize their authentic knowledge and distribute this in public spaces.

In comparison with "Home" and "The Icebreaker", the poetic voice in "Empathy" confirms refugees' inhumane sea crossing and how impossible it is for the outsiders not to feel moved by the humanity solidarity to help them get proper aids. Refugee's predicament is too tragic, as seen in the comparison used by the voice to state her gratefulness as opposed to refugees' dark journey. Therefore, the critical voice in the poem questions the moral consequences of most people's spectatorship within the rise of the crisis. FRE helps the voice in the poem to intermingle the personal view of a mother within a family with the public display of asylum seekers, i. e. her reflection of safety against refugee's unsafe condition as seen in public space. The meditating function of activists/mother enables the readers to listen, observe, and analyze their privilege to empathize. This act of comparison portrays the inevitable criticism of public empathy that 
dominates public spectatorship, instead of solidarity, towards refugee's occurrence in the media. As a consequence, the poem formulates a dominant transnational feminist praxis (Swarr; Lock; Nagar in Le Espiritu \& Duong, 2018) and fights for the distribution of refugees' stories, which focuses on the readers' uncomfortable spatial and temporal circumstances within the refugee's context.

The poetic expression in the three poems reveals the powerful poetic voice that engages in refugees' powerful knowledge-making and social discussion trigger while at the same time, construct the question of privilege in refugee discourse. By considering the dual viewpoints of refugees, forced-migratory experience, the three poems reconstruct the meaning-making process that triggers the readers in the spirit of solidarity for humanity and a more inclusive community and social interaction.

\section{The Intersection of Public and Private in Refugee's Poetic Expression}

The collision of the public and the private in the three poems reflect the actual experiences of the refugees who must leave home behind and survive by navigating the host country's codes and cultures (Castellani, 2019). The social interaction is inevitable once they arrive on the new land. Therefore, the speaker in "The Icebreaker" teases how awkward the society was once she revealed she was once a refugee. The introvert being, though, the speaker declared at the beginning of "The Icebreaker", she tried to get involved in social interaction with the society of the host. Instead of despairing in sudden grief, she felt

\section{You've always loved to throw off people with the refugee line, it's sometimes The best icebreakers for an introvert like you. You chuckle. If pressed, you Tell them that you spent the summer of 1998 underneath a bed with your sister Afraid a bomb might rip the ceiling.}

The bold sentence reflects how the juxtaposition of a refugee's grim private experience with her humorous sociable attitude creates a new sense of owning the conversation, where the speaker can direct where the talk flows. Her act of laughing at specific mirthless warfare memories in the past depicts the personhood of an ex-refugee who claims her historical yet personal narrative in public.

Shire's "Home" has inspired many protests regarding global inequalities, especially in the context of refugees. The first two lines, which stated, "No one leaves home unless//home is the mouth of a shark//" signifies the real situations of global forced migration. The title indicates that the poet presents the ugly reality about what happened back at home and the newly claimed home of the present, which forces them to flee and seek shelter in a foreign land. Home is indeed a dynamic concept which carries with it the historical and cultural stance to receive the concept of permanent departure.

"Home" is intense in constructing the terror-starting from the shift of sociopolitical condition at home to the ambivalence of still "carried the anthem under your breath// only tearing up your passport in an airport toilet// sobbing as each mouthful of paper// made it clear that you wouldn't be going back." The private and familiar turns into the strange and foreign. This intersection between the private lives of the refugee bridges them to make a new home more bearable a predicament in seeking shelter. She reflects,

The
Go home blacks
Refugees
Dirty immigrants
Asylum seekers
Sucking our country dry
Niggers with their hands out
They smell strange...
How do the words
The dirty looks
Roll off your backs
Maybe because the blow is softer
Than a limb torn off

The host country's mocks, their resistance to refugees' sufferings, the harsh verbal and physical response upon seeing the asylum seekers' arrival provide a better situation than the more absurd threats back 
home. This shift marks a meaning changing of home, instead of being a place to return, to be a constant journey to adapt to new circumstances and a rigid concept of survival. Borrowing the term of 'the aesthetic of nightmare realism' (Sakr, 2018), Shire culminates her absurd reality shared with most war-torn refugees. However, even if it is full of shame, painful, and ugly, she enacts those experiences boldly in the form of a poetic monologue.

Stallings, in "Empathy", transfers her helplessness to take a stance before the issues of the refugee crisis and the rise of a far-right movement contributing to the making of global forced-migration phenomenon. She is grateful she did not become one of the refugees, yet her position is helplessly ambivalent when she stated,

\section{Empathy isn't generous,}

It's selfish. It's not being nice

To say I would pay any price

Not to be those who'd die to be us

She criticizes public response toward this extraordinary humanity crisis by attacking their hypocrisy of gratefulness in between the tragic refugees' cataclysm. The private gratefulness within the public catastrophe is juxtaposed in the way that public morality is no longer taken for granted.

\section{Dark Humour and Comparison as Resistance}

Unlike "Home", which is very consistent in increasing the tension of fearful war, "The Icebreaker" gives space for a humorous intervention. The social conduct which often fosters people to become amiable is not the motive; she is frank in her introvert personality but finds an awkward pause in social responses to her narrative farcical.

They become awkward, and you laugh even more. You remember that strangely

Enough you spent that whole summer too laughing away. Like when your aunty

Crossed your city waving around white flag. Just in case.
The poet's paradox is visible in public spaces, which turns to be constant guilt when she is in an individual circumstance. It shows that dark humor is a social tool by which the personhood stays in two realms: public and private. The urge to adapt to a new land and foreign customs cultivates the poet's social interaction, which veils the lingering vulnerable effect of war.

Consequently, the recognition of the past is a brave act of enacting one's personhood in society so that the focus is not on how pity from the outside takes everyone's painful past. "The Icebreaker" hence is a compelling trajectory that explores this social conduct of making ways for social blending a robust control over society's reaction to an unusual throbbing experience.

Similar to what Said (2013) admitted that exile, which in this case refers to refugees, compensates the disorienting loss by creating a new world to rule. "The Icebreaker" performs such a tiny niche for the poet, at least in her social role.

Shire's "Home", on the other hand, traces the past aching memories by staying true to the intense emotion the forced-migration carries. The robust honesty to admit the grim past haunting the poet to flee home provides a merciless description of its changing role from protecting to threatening. The portrayal of hardship over hardship before the journey was taken, when it was done, and after it was executed was vividly told all through the poem.

Shire's method of juxtaposing the hardships at home and those in foreign land reveals her act of resisting injustice befell her and her people. Similar to Said (2013), who concluded upon his conversation with Noubar-an Armenian friend-that exile is sometimes better than staying behind or not getting out. The table maps the poem's juxtaposition of the poet's ambivalence in narrating forced migration. 
Table 1 The Comparison which Shows Ambivalence in Refugees' Poetical Narratives

\begin{tabular}{|c|c|c|}
\hline Category & \multicolumn{2}{|c|}{ Comparison } \\
\hline $\begin{array}{l}\text { The shift from familiar } \\
\text { to foreign }\end{array}$ & $\begin{array}{l}\text { the boy you went to school with// } \\
\text { who kissed you dizzy behind the old } \\
\text { tin factory }\end{array}$ & $\begin{array}{l}\text { is holding a gun bigger than his } \\
\text { body }\end{array}$ \\
\hline $\begin{array}{l}\text { the ambivalence of } \\
\text { nationality }\end{array}$ & $\begin{array}{l}\text { then you carried the anthem } \\
\text { under// your breath }\end{array}$ & $\begin{array}{l}\text { Tearing up your passport in an } \\
\text { airport toilet }\end{array}$ \\
\hline $\begin{array}{l}\text { The dangerous } \\
\text { journey }\end{array}$ & $\begin{array}{l}\text {... no one puts their children in a } \\
\text { boat } \\
\text { no one spends days and nights in the } \\
\text { stomach of a truck }\end{array}$ & $\begin{array}{l}\text { Unless the water is safer than the } \\
\text { land } \\
\text { unless the miles traveled // } \\
\text { means something more than a } \\
\text { journey. }\end{array}$ \\
\hline Choicelessness & $\begin{array}{l}\text { no one chooses refugee camps// } \\
\text { or strip searches where your// } \\
\text { the body is left aching// or prison }\end{array}$ & $\begin{array}{l}\text { because prison is safer// } \\
\text { than a city of fire// } \\
\text { and one prison guard } \\
\text { in the night// } \\
\text { is better than a truckload// } \\
\text { of men who look like your father }\end{array}$ \\
\hline The unwelcoming host & $\begin{array}{l}\text { go home blacks// } \\
\text { refugees// } \\
\text { dirty immigrants// } \\
\text { asylum seekers// } \\
\text { sucking our country dry// } \\
\text { niggers with their hands out// } \\
\text { they smell strange// } \\
\text { savage }\end{array}$ & $\begin{array}{l}\text { maybe because the blow is } \\
\text { softer// } \\
\text { than a limb torn off// } \\
\text { or the words are more tender// } \\
\text { than fourteen men// between } \\
\text { your legs }\end{array}$ \\
\hline $\begin{array}{l}\text { A sense of place to } \\
\text { return }\end{array}$ & I want to go home & $\begin{array}{l}\text { but home is the mouth of a } \\
\text { shark// } \\
\text { home is the barrel of the gun }\end{array}$ \\
\hline
\end{tabular}

The comparison acts as a robust contestation between the past and the present, even when both are utterly distressing. The choicelessness triggers refugee-voice in the poem to decide, and this is how subjectivity performs in refugee discourse. The irony of hardships shapes a decision mechanism, which enables them to transform fears into action.

The case of Stallings' comparison in "Empathy" is even darker. She touches the inevitability of socio-political dynamics, which helps to cause the refugee crisis that helps create the binary of the lucky/unlucky or privileged/underprivileged or insider/ outsider. The global humanity catastrophe left unaffected people with luxury to reflect their luck by comparing it to others' lack of luck. It happens in the micro concept of humble gratefulness, which encourages people to reflect on how grateful they are compared to the less grateful ones. Coming to Stalling's public activism in helping to cope with the refugee crisis in Athens as the off-poetic context, we may come to realize her powerful expression in meditating moral emotions in which the collocation between the privileged and under-privileged articulate.

My love, I'm grateful tonight Our listing bed isn't a raft 


\author{
Precariously adrift \\ As we dodge the coast guard \\ light, \\ And clasp hold of a girl and a \\ boy.
}

Through the mass media publication of the photograph of the three-year-old Syrian boy Alan Kurdi lying dead on the beach, the public sees the minor representation of the refugee crisis evocatively and coalesced more strongly via social media (Dahlgren, 2016). Stallings is one of the activists who roll up her sleeve in helping to distribute aids for refugees in Athens. Her direct contact with refugees left her dejected, which often fostered her to make short poems or epigrams in order to process what she had just been through (Haven, 2017).

In Poet's Note section in Women's Voices for Change's article Poetry Sunday (Foust, 2018): "Empathy" by A. E. Stallings, she said that,

"... this sense that children were drowning in the same water we swam in haunted me all summer, the sense of the Aegean as dangerous and full of death as well as winedark or Santorini blue, and that the same element that caressed my children pulled others under. I had dreams about making that crossing. It was maybe that heightened sense of vigilance and danger you just have as a parent of young children, the way you can't avoid reading terrible news stories about mishaps and accidents."

Her direct encounters intensified by the news circulation inspiring her "Empathy" as she felt it unfair to tell the plight of refugees in their viewpoints. Therefore, she wrote the poem of refugees using her own critical observation to move and to awaken those who do not need to experience it themselves.

The subjectivity of refugees in "Empathy" requires readers to digest their decision making to flee in the acts of:

- Dodge the coast light - clasp hold of a girl and a boy

- Wake - kids in the thin hours

- Hand over - cash to one of the smuggling rackets
- buy cheap life jackets

- scan the sky for a mark (that demarcates a shore)

- die to be 'us'

The sight which observes refugee's phenomenon in the viewpoint of non-refugee makes it more vibrant with nuances, in which society sees the tragic phenomenon within their safety. Nevertheless, the ending questions on refugee's right position showing any sign of empathy, which is selfish rather than generous. She provides an open-ended discourse about empathy and its moral consequences. However, empathy, which is critically portrayed in the poem, tends to make the readers uneasy. The voice encourages readers' response to the crisis by its revelation of the ugly truth about the term empathy.

\section{Conclusion}

This study aims to comprehend how refugees' poems depict their subjectivity as opposed to the media portrayal that mostly portrays them as victims or objects of pity. This study argues that the poetic platform produces a powerful resistance to such a display. "The Icebreaker" packs densely with dark humor to adapt to and take control of mingling in social conversation in the host country. As opposed to the friendly voice in "The Icebreaker", "Home" incorporates comparison in commemorating the speaker's meditation on her perilous journey to safety. Both poems fuse the private and the public to present a comprehensive experience from which their subjectivity emerges.

The third poem, "Empathy", by A. E. Stallings takes readers to explore humanity catastrophe and to question the equivocal term of empathy. The recognition of the subjectivity of the refugees articulates in the poem by observing the on refugee's viewpoint, which enables readers to recognize the ambiguous side of their empathy. The focus, however, is not on the problematic impact of empathy but on the portrayal of the refugees whose courage cannot guarantee a safe life, but they carry on instead.

The future study may take its stance from the mix of poem's linguistic exploration 
engaged with its contextual background or philosophical theory about spectatorship morality and relational empathy to help shaping a more thorough analysis about the global refugee crisis so that we can manifest a more inclusive society and spread humanitarian solidarity by the transcendence of poetic vision and its post-reading experience.

\section{References}

Anna-Leena Toivanen. (2017). The Unattainable Mediterranean: Arrested Clandestine Odysseys in Sefi Atta's "Twilight Trek" and Marie NDiaye's Trois femmes puissantes. Research in African Literatures, 47(4), 133. https://doi.org/ 10.2979/reseafrilite.47.4.08.

Boochani, B. (2018). Manus prison poetics/our voice: revisiting 'A Letter From Manus Island,' a reply to Anne Surma. Continuum, 32(4), 527-531. https://doi.org/ 10.1080/10304312.2018.1501796.

Cahill-Booth, L. (2013). Walcott's sea and Caribbean geomythography. Journal of Postcolonial Writing, 49(3), 347-358. https://doi.org/10.1080/17449855.201 2.703621.

Castellani, C. (2019, October). On the Universal Urgency of Immigrant Literature. Retrieved from https://lithub.com/onthe-universal-urgency-of-immigrantliterature/.

Chouliaraki, L., \& Zaborowski, R. (2017). Voice and community in the 2015 refugee crisis : a content analysis of news coverage in eight European countries A Content Analysis of news coverage in Eight. International Communication Gazette, 79(6-7), 613-635. https://doi. org/10.1177/1748048517727173.

Dahlgren, P. (2016). Moral Spectatorship and Its Discourses: The "Mediapolis" in the Swedish Refugee Crisis. Javnost - The Public, 23(4), 382-397. https://doi. org/10.1080/13183222.2016.1247332.

Foust, R. (2018). Poetry Sunday: "Empathy" by A. E. Stallings. Retrieved January 14, 2020, from https://womensvoicesforchange. org/poetry-sunday-empathy-by-a-estallings.htm.

Gallien, C. (2018a). Forcing displacement: The postcolonial interventions of refugee literature and arts. Journal of Postcolonial Writing, 54(6), 735-750. https://doi. org/10.1080/17449855.2018.1551268.

Gallien, C. (2018b). Forcing displacement: The postcolonial interventions of refugee literature and arts. Journal of Postcolonial Writing, 54(6), 735-750. https://doi. org/10.1080/17449855.2018.1551268.

Gallien, C. (2018c). "Refugee Literature": What postcolonial theory has to say. Journal of Postcolonial Writing, 54(6), 721-726. https://doi.org/10.1080/17449855.201 8.1555206 .

Haven, C. (2017). Crossing Borders. Retrieved January 4, 2020, from https://www. poetryfoundation.org/articles/144785/c rossing-borders

Hopkins, L. (2009). Why narrative? Reflections on the politics and processes of using narrative in refugee research. TAMARA: Journal of Critical Postmodern Organization Science, 8(8), 135-145. Retrieved from http://search. ebscohost.com/login.aspx?direct=true\&d $b=b u h \& A N=61867944 \&$ site $=$ ehost-live.

Hyndman, J. (2010). "Introduction: The Feminist Politics of Refugee Migration." Gender, Place, and Culture, 17(4), 453459.

Le Espiritu, Y., \& Duong, L. (2018). UC San Diego. SIGNS, 43(3), 587-615. https://doi.org/10.1086/695300.

Lewis, D., Rodgers, D., \& Woolcock, M. (2008). The fiction of development: Literary representation as a source of authoritative knowledge. Journal of Development Studies, 44(2), 198-216. 
89828.

Lubkemann, S. C. (2008). Culture in Chaos: An Anthropology of the Social Condition of War. Chicago: University of Chicago Press.

Said, E. W. (2013). Reflections on Exile and Other Essays (ebook). Retrieved from www.grantabooks.com.

Saint, L. (2012). Reading subjects: Passbooks, literature, and apartheid. Social Dynamics, 38(1), 117-133. https://doi.org/10.1080 /02533952.2012.700178.

Sakr, R. (2018). The more-than-human refugee journey: Hassan Blasim's short stories. Journal of Postcolonial Writing, 54(6), 766-780.

https://doi.org/10.1080/17449855.201 8.1551269 .

Sellman, J. (2018). A global postcolonial: Contemporary Arabic literature of migration to Europe. Journal of Postcolonial Writing, 54(6), 751-765. https://doi.org/10.1080/17449855.201 8.1555207.

Shields, T. L. (2018). Collisions: History, home, and storytelling. Cultural Dynamics, 30(12), 3-12. https://doi.org/10.1177/ 0921374017751767.

Stallings, A. E. (2018). Like. Farrar, Straus, and Giroux.

Stan, C. (2018). A life without a shoreline: Tropes of refugee literature in Jenny Erpenbeck's Go, Went, Gone. Journal of Postcolonial Writing, 54(6), 795-808. https://doi.org/10.1080/17449855.201 8.1551272 .

Surma, A. (2018). In a different voice: 'a letter from Manus Island' as poetic manifesto. Continuum, 32(4), 518-526. https:// doi.org/10.1080/10304312.2018.14684 14.

Swarr; Lock, Amanda; Nagar, R. (2010). Introduction: Theorizing Transnational Feminist Praxis. In Critical Transnational Feminist Praxis (pp. 1-22). Albany, NY:
SUNY Press.

Warsan Shire. (n.d.). Home. Retrieved January 4, 2020, from https://www.facinghistory. org/standing-up-hatredintolerance/warsan-shire-home.

Yovanka Paquete Perdigao. (2015). The Icebreaker. Retrieved January 4, 2020, from https://brittlepaper.com/2015/11/ icebreaker-yovanka-paquete-perdigaoafrican-poem/. 